\title{
Pemanfaatan Lumpur Tambak Garam untuk Membuat Telor Asin di Desa Lembung Galis Pamekasan
}

\author{
Usman \\ Institut Agama Islam Negeri Madura \\ ualadipni@gmail.com
}

\begin{abstract}
Madura has a long coastline and a hot, dry season, which has made Madura one of the largest producers of salty white gold or salt in Indonesia, which has earned Madura the nickname Pulau Garam (The Island of Salt). Of course, as the largest salt producer, this fact makes Madura has long and large salt ponds. This is the primary basis to be used as a locus of community service research. It is the use of salt pond mud as an ingredient for salting eggs, which will impact the minimum cost of materials for the community. The method used in this service is based on Participatory Action Research (PAR). The result is that the mud from the salt ponds that comes from salt deposits in the form of mud, which is usually discarded by the pond's farmers, can be used as a salting material for duck eggs, which are usually made from a mixture of soil with salt. The trials conducted by researchers and the regional society regarding the use of salt pond mud to become one of the useful ingredients for coastal communities to make salted eggs, so this is also beneficial for the minimal capital in making salted eggs. The results of salted eggs by utilizing the salt pond mud are quite good and sieve for consumption. Besides that, the abundant material of salt pond mud in the coastal areas of Madura is an alternative material for making salted eggs. The community can use salt pond mud as the main ingredient for making salted eggs.
\end{abstract}

Keywords: Mud; Salt Pond; PAR; Salty Egg

\begin{abstract}
Abstrak
Madura yang mempunyai garis pantai yang panjang dan mempunyai musim kemarau yang panas menjadikan Madura sebagai salah satu penghasil emas putih yang asin atau garam terbesar di Indonesia, ha ini yang menjadikan Madura mendapat julukan sebagai pulau garam. Tentu, sebagai penghasil garam terbesar, fakta ini menjadikan madura pemilik tambak garam yang panjang dan besar. Hal ini manjadi dasar utama untuk dijadikan locus penelitian pengabdian kepada masyarakat. Diantaranya pemanfaatan lumpur tambak garam sebagai bahan pengasinan telor asir yang akan berdampak pada minimalnya biaya bahan untuk masyarakat. Metode yang digunakan dalam pengabdian ini berbasis Participatory action research (PAR). Hasilnya Lumpur dari tambak garam yang berasal dari endapan garam berupa lumpur yang biasanya di buang oleh para petani tambak bisa
\end{abstract}


di manfaatkan sebagai bahan pengasin telur bebek yang biasanya terbuat dari campuran tanah yang diberi garam. Hasil uji coba yang dilakukan oleh peneliti dan masyarakat tentang pemanfaatan lumpur tambak garam untuk menjadi salah satun bahan yang bermanfaat bagi masyarakat pesisir untuk membuat telor asin, sehingga ini juga bermanfaat terhadap semakin minimalnya modal dalam pembuatan telor asin. Hasil telor asin dengan memanfaatkan lumpur tambak garam cukup baik dan ayak untuk di konsumsi selain itu bahan lumpur lumpur tambak garam yang melimpah di daerah pesisir madura menjadi bahan alternatif dalam membuat telor asin. Masyarakat dapat memanfaatkan lumpur tambak garam sebagai bahan utama membuat telor asin.

Keywords: Lumpur; Tambak Garam; PAR; Telor Asin

\section{Pendahuluan}

Salah satu kewajiban dunia akademis perguruan tinggi baik negeri maupun swasta di Indonesia adalah pengabdian kepada masyarakat. Baik yang bersifat mandiri maupun yang bersifat dibiayai oleh institusi negara. Pengabdian kepada masyarakat dalam berbagai bentuk kegiatan dilapangan sebagai upaya meningkatkan kapasitas masyarakat dalam berbagai sektor sosial kemasyarakatan.

Dosen sebagai salah satu elemen utama dalam sistem pendidikan di perguruan tinggi. Mempunyai tugas dan tanggungjawab yang besar, karena dosen sangat penting dalam mewujudkan tujuan pendidikan nasional yang secara substansi termaktub dalam Undang-undang Dasar 1945, yaitu mencerdaskan kehidupan bangsa, meningkatkan kualitas manusia Indonesia, yang meliputi kualitas iman/takwa, akhlak mulia, dan penguasaan ilmu pengetahuan, teknologi, seni, serta mewujudkan masyarakat Indonesia yang maju, adil, makmur, dan beradab. Untuk melaksanakan fungsi, peran, dan kedudukan yang sangat strategis tersebut, diperlukan dosen yang profesional.

Dosen dinyatakan sebagai pendidik profesional dan ilmuwan dengan tugas utama mentransformasikan, mengembangkan, dan menyebarluaskan ilmu pengetahuan, teknologi, dan seni melalui pendidikan, penelitian, dan pengabdian kepada masyarakat. profesional dinyatakan sebagai pekerjaan atau kegiatan yang dilakukan oleh seseorang dan menjadi sumber penghasilan kehidupan yang memerlukan keahlian, kemahiran, atau kecakapan yang memenuhi standar mutu atau norma tertentu serta memerlukan pendidikan profesi (Republik Indonesia, 2005: 2).

Kompetensi tenaga pendidik, khususnya dosen, diartikan sebagai seperangkat pengetahuan, keterampilan dan perilaku yang harus dimiliki, dihayati, dikuasai dan diwujudkan oleh dosen dalam melaksanakan tugas profesionalnya. Kompetensi tersebut meliputi kompetensi pedagogik, kompetensi kepribadian, kompetensi sosial dan kompetensi profesional.

Pulau madura yang juga terkenal dengan pulau garam, karena salah satu penghasil garam utama Indonesia. Bahkan, peneliti senior madurologi 
menyatakan Madura akan menjadi pusat penghasil emas putih atau emas asin, akan terus berlanjut karena di dukung oleh letak geografis yang strategis, selain gas dan hasil alam lainnya (Abadi, 2019). Ini selaras dengan hasil riset yang menyatakan Garam menjadi salah satu komoditas strategis nasional yang kedudukannya tidak kalah penting jika dibandingkan dengan kebutuhan pokok lainnya, mengingat peran dan fungsi yang dimilikinya. Selain berfungsi sebagai bahan pangan, garam juga berfungsi sebagai bahan baku bagi industri dalam negeri. Sebagai bahan pangan yang mengandung unsur mineral yang dibutuhkan oleh manusia, Sodium dan Klor $(\mathrm{NaCl})$, keberadaan garam tentu mutlak diperlukan di tiap rumah tangga masyarakat. Sementara sebagai bahan baku industri, garam menjadi bahan baku penting bagi industri makanan olahan, industri kimia atau farmasi, industri penyamakan kulit dan industri pengeboran minyak. Melihat peran esensial garam bagi konsumsi rumah tangga yang menyangkut ketahanan pangan dan pemenuhan gizi nasional serta fungsi sebagai bahan baku bagi industri di dalam negeri, tidak heran apabila garam kemudian juga dijuluki sebagai salah satu "komoditas politik" (Ardiyanti, 2016: 7).

Berdasarkan data Kementerian Kelautan dan Perikanan (KKP, 2015), produksi garam nasional pada tahun 2015 mencapai 2,84 juta ton. Sebanyak 2,5 juta ton diproduksi oleh garam rakyat yang digunakan untuk memenuhi kebutuhan garam konsumsi, dan sisanya berupa garam industri yang diproduksi PT. Garam (Munadi, 2016: 2). Ini menunjukkan bahwa petani garam yang menghasilkan garam rakyat begitu dominan dengan lahan yang berada digaris pantai yang panjang.

Setelah melalui observasi yang mendalam dalam rangka pengabdian kepada masyarakat pesisir yang ada di desa lembung pesisir kecamatan galis kabupaten pamekasan. Terdapat fenomena yang menarik perhatian, diantaranya adalah pembuangan sisa-sisa endapan garam yang terjadi setelah panen garam dilakukan oleh para petani garam di daerah ini. Setelah melakukan diskusi dengan petani dan warga sekitar akhir akan dilakukan uji coba pemanfaatan lumpur tambak untuk pembuatan telor asin.

\section{Metode}

PAR merupakan suatu pendekatan untuk mewujudkan perubahan sosial yang mencakup perubahan paradigma/pemahaman, tindakan, dan relasi sosial yang didasarkan pada prinsip kesetaraan, kebersamaan, dan keadilan, dan kemerdekaan. Perubahan tersebut bertujuan mengubah masyarakat pasif kepada masyarakat aktif. Inti teori dan praktek PAR adalah sebagai berikut: 1 . Sebuah gerakan sosial dengan semangat pembebasan diri dari belenggu ideologi dan relasi kuasa yang menghambat manusia mencapai perkembangan harkat dan martabat kemanusiaannya; 2. Sebuah upaya dan proses yang memungkinkan masyarakat memiliki kesempatan untuk menguasai ilmu pengetahuan dan membangun kekuatan politik melalui penelitian kritis, pendidikan pembebasan, dan tindakan sosial-politik; 3. Proses masyarakat membangun kesadaran diri melalui dialog dan refleksi kritis; 4. Riset sosial dengan prinsip: a. Produksi pengetahuan oleh 
masyarakat (selanjutnya disebut komunitas) mengenai agenda kehidupan mereka sendiri, b. Partisipasi dalam pengumpulan dan analisa data, dan c. Kontrol mereka terhadap penggunaan hasil riset. 5. Orientasi komunitas lebih pada proses perubahan relasi sosial (Transformasi sosial) (LPM IAIN Madura, 2018: 1).

\section{Hasil dan Pembahasan}

\section{a. Hasil}

Setelah melalui tahapan pelaksanaan pengabdian kepada masyarakat dengan metode Participatory Action Research (PAR) dihasilkan sebagai berikut: Pertama, Lumpur dari tambak garam yang berasal dari endapan garam berupa lumpur yang biasanya di buang oleh para petani tambak bisa di manfaatkan sebagai bahan pengasin telur bebek yang biasanya terbuat dari campuran tanah yang diberi garam.

Kedua, Hasil uji coba yang dilakukan oleh peneliti dan masyarakat tentang pemanfaatan lumpur tambak garam untuk menjadi salah satun bahan yang bermanfaat bagi masyarakat pesisir untuk membuat telor asin, sehingga ini juga bermanfaat terhadap semakin minimalnya modal dalam pembuatan telor asin.

Ketiga, Hasil telor asin dengan memanfaatkan lumpur tambak garam cukup baik dan ayak untuk di konsumsi selain itu bahan lumpur tambak garam yang melimpah di daerah pesisir madura menjadi bahan alternatif dalam membuat telor asin.

\section{b. Pembahasan Pengabdian Kepada Masyarakat}

Pulau Madura yang mempunya empat kabupaten diantaranya adalah Sumenep, Pamekasan, Sampang dan Bangkalan memang dikenal bermusim kemarau yang membuat daerahnya kering lebih panjang, Sedikitnya sungai dan terbatasnya sumber air tawar. Daratan Madura relatif datar di sisi selatan, dengan dataran tinggi di tengah, dan pantai utara yang berbeda ketinggian. Suhu rata-rata Pulau Madura 26,9 derajat celsius, dengan kemarau panjang antara 4 sampai 5 bulan (rata-rata bulan kering 2 sampai 4 bulan).

Meski garam hanya dihasilkan di sepanjang pantai Selatan Madura. Sedikitnya sungai dan muara membuat kawasan Selatan memiliki air laut berkadar garam tinggi. Proses pembuatan garam rakyat di Pulau Madura kerap disebut cara 'Madurese' atau cara orang Madura, di mana pembuatan garam dengan kristalisasi air laut secara total, garam diambil mulai dari lapisan terbawah hingga atas. Para petani garam secara tradisional memindahkan air laut antarmeja garam (Siap Bangun Negara, 2019). Oleh karena itu Madura tentunya menjadikannya mempunyai kelebihan sekaligus menjadi salah satu kelemahanya dalam konteks alam dan sosial masyarakatnya. Sudah begitu banyak kajian dan pengabdian yang dilakukan oleh berbagai kalangan dengan berbagai variasi teknik, salah satu berbasis partisipasi langsung dan bercorak pemberdayaan kepada masyarakat. 
Pendekatan penelitian yang dipakai adalah riset aksi. Di antara namanamanya, riset aksi sering dikenal dengan PAR atau Participatory Action Research. Adapun pengertian riset aksi menurut Corey (1953) adalah proses di mana kelompok sosial berusaha melakukan studi masalah mereka secara ilmiah dalam rangka mengarahkan, memperbaiki, dan mengevaluasi keputusan dan tindakan mereka. Pada dasarnya, PAR merupakan penelitian yang melibatkan secara aktif semua pihak-pihak yang relevan (stakeholders) dalam mengkaji tindakan yang sedang berlangsung (di mana pengamalan mereka sendiri sebagai persoalan) dalam rangka melakukan perubahan dan perbaikan ke arah yang lebih baik. Untuk itu, mereka harus melakukan refleksi kritis terhadap konteks sejarah, politik, budaya, ekonomi, geografis, dan konteks lain-lain yang terkait. Yang mendasari dilakukannya PAR adalah kebutuhan kita untuk mendapatkan perubahan yang diinginkan (LPM IAIN Sunan Ampel Surabaya, 2008: 27).

Pada pengabdian yang peneliti lakukan dilakukan di Desa Lembung Kecamatan Galis Kabupaten Pamekasan, merupakan daerah pesisir pantai yang terdapat begitu banyak tambak garam yang dimiliki oleh masyarakat atau dalam konteks pemerintah di sebut sebagai garam rakyat. Sebagai daerah penghasil garam terbesar di Indonesia, tentu menjadi daya tarik tersendiri untuk melakukan penelitian partisipasi yang langsung di lapangan. fokusnya adalah manfaat tambak garam bagi ibu-ibu yang tidak menjadi buruh di tambak garam. Pengabdian ini lebih cenderung dalam konteks geografi dan ekonomi.

PAR terdiri dari tiga kata yang selalu berhubungan seperti daur (siklus), yaitu partisipasi, riset, dan aksi. Artinya hasil riset yang telah dilakukan secara partisipatif kemudian diimplementasikan ke dalam aksi. Aksi yang didasarkan pada riset partisipatif yang benar akan menjadi tepat sasaran. Sebaliknya, aksi yang tidak memiliki dasar permasalahan dan kondisi subyek penelitian yang sebenarnya akan menjadi kontraproduktif. Namun, setelah aksi bukan berarti lepas tangan begitu saja, melainkan dilanjutkan dengan evaluasi dan refleksi yang kemudian menjadi bahan untuk riset kondisi subyek penelitian setelah aksi. Begitu seterusnya hingga kemudian menjadi sesuatu yang ajeg. Oleh Stephen Kemmis proses riset aksi digambarkan dalam model cyclical seperti spiral. Setiap cycle memiliki empat tahap, yaitu rencana, tindakan, observasi, dan refleksi.

Menurut Winter (1989) dalam riset aksi terdapat enam prinsip yang dijadikan petunjuk melakukan riset. Enam prinsip tersebut adalah: Pertama, Refleksi kritis Kebenaran dalam lingkungan sosial sangat relatif dan tergantung pada subyek penelitian. Pertimbangan situasi yang tercantum dalam catatan-catatan lapangan, dokumen resmi harus telah mendapat pengakuan secara implisit dari subyek. Maka, barulah bisa dikatakan bahwa fakta tersebut benar apa adanya. Prinsip refleksi kritis menjamin orangorang untuk mempertimbangkan isu-isu, proses-proses, dan membuat interpretasi, asumsi, dan penilaian secara eksplisit. Dengan cara ini pertimbangan praktis bisa menyempurnakan pandangan-pandangan teoritis. 
Kedua, Dialektika kritis realitas sosial yang partikular bisa menjadi valid secara konsensual, yang mana bahasa menjadi sarana penyampaiannya. Fenomena pada umumnya dikonseptualisasikan melalui dialog. Maka dari itu, prinsip dialektika kritis menghendaki pemahaman pengaturan hubungan antara fenomena dan konteksnya, dan antara elemen-elemen yang menyusun fenomena. Elemen kunci adalah mereka yang bertentangan dengan yang lainnya, dan itu merupakan salah satu yang hampir suka menciptakan perubahan.

Ketiga, Kolaborasi sumber daya partisipan dalam proyek riset aksi adalah peneliti juga. Prinsip kolaborasi sumber daya ini berpraduga bahwa ide tiap orang sama signifikannya sebagai potensi sumber daya untuk membuat interpretasi, kategori analisis yang dinegosiasikan di antara partisipan. Hal ini ditujukan untuk menghindari kemiringan kredibilitas dari pemegang ide terdahulu. Selain itu, secara khusus hal tersebut dapat menimbulkan kesadaran dan toleransi dari adanya kontradiksi antara banyak sudut pandang dan di dalam satu sudut pandang pun.

Keempat, Kesadaran resiko proses perubahan berpotensi mengancam semua cara yang telah berlaku sebelumnya, dan itu menciptakan ketakutan secara psikis di antara para praktisinya. Salah satu ketakutan yang utama adalah datang dari ego yang menahan diri dari diskusi terbuka terhadap interpretasi, ide, dan penilaian orang lain. Seorang inisiator riset aksi akan menggunakan prinsip ini untuk menenangkan ketakutan-ketakutan lain dan mengundang partisipasi dengan menegaskan bahwa masyarakat juga akan menjadi subyek dari proses yang sama, dan bagaimana pun juga hasil akhirnya adalah belajar bersama.

Kelima, Struktur plural alam penelitian pada umumnya terdiri dari berbagai macam pandangan, komentar, dan kritik, dalam rangka menuju berbagai kemungkinan aksi dan interpretasi. Pendalaman struktur yang plural ini menghendaki banyak teks untuk pelaporannya. Hal ini berarti akan banyak pertimbangan secara eksplisit dengan komentar yang kontradiktif dan berbagai macam panduan untuk aksi. Laporan pada dasarnya adalah sebuah tindakan sebagai dukungan untuk meneruskan diskusi di antara kolaborator daripada memutuskan sebuah konklusi akhir dari sebuah fakta.

Keenam, Teori, praktek, dan transformasi Bagi para praktisi riset aksi, teori menginformasikan praktek, dan praktek menyempurnakan teori menuju upaya transformasi yang terus- menerus. Dalam lingkungan apa pun, aksi tiap orang didasarkan pada asumsi, teori, dan hipotesis yang secara implisit dipegang teguh, dan dengan tiap hasil observasi pengetahuan teoritik akan bertambah. Selain prinsip-prinsip di atas, PAR mengharuskan adanya pemihakan baik bersifat epistemologis, ideologis, maupun teologis dalam rangka melakukan perubahan yang signifikan. Pemihakan epistemologis mendorong peneliti untuk menyadari bahwa banyak cara untuk melihat masyarakat. Pemihakan ideologis mengharuskan peneliti memiliki empati dan kepedulian tinggi terhadap semua individu dan kelompok masyarakat yang lemah, tertindas, terbelenggu, dan terdominasi. Pemihakan teologis menyadarkan peneliti bahwa teks-teks agama yang termuat dalam Al-Qur'an 
dan Hadits memberikan dorongan yang besar dengan imbalan pahala yang besar pula kepada semua orang beriman yang melakukan upaya-upaya pertolongan dan pemberdayaan terhadap individu maupun kelompok masyarakat dhu'afa, mustadh'afin, dan mazlumin (LPM IAIN Sunan Ampel Surabaya, 2008: 29).

Pada penelitian dan pengabdian ini peneliti mengkolaborasikan kedua metode yang disebutkan oleh Stephen Kemmis dan Winter proses riset aksi digambarkan dalam model cyclical seperti spiral. Setiap cycle memiliki empat tahap, yaitu rencana, tindakan, observasi, dan refleksi dan enam tahapan yang disebutkan oleh Winter. Namun, kerangka utama tearing menggunakan lebih pada metode Stephen Kemmis untuk tahap pertama yakni melakukan perencanaan dengan melakukan langkah-langkah sebagai berikut:

Pertama, melakukan persiapan awal dengan melakukan survey lokasi atau locus yang akan dijadikan tempat penelitian, melakukan wawancara awal dengan masyarakat sekitar serta tokoh masyarakat. Selanjutnya mempersiapakan rencana aksi dan persiapan administrasi untuk kelancaran kegiatan penelitian dan pengabdian kepada masyarakat. $\mathrm{Bu}$ Siti mengatakan "Masyarakat disini sebagian adalah nelayan dan bekerja sebagai petani garam, pada musim-musim panas adalah musim untuk bertani garam, baik milik sendiri ataupun menggarap tambak garam milik juragannya".

Pada survey awal ditemukan bahwa para petani tambak terlihat membersihkan tambak garam yang akan diisi air laut dengan cara mengalirkannya dengan mesin-mesin pompa air yang relatif bertenaga besar. Ini dilakukan untuk menghemat waktu dan biaya dibandingan menggunakan cara klasik dan manual seperti sebelumnya. Terlihat juga sebagian besar dari tambak garam itu diberi alas untuk mendapatkan garam yang lebih putih dan bersih.

Dapat di pahami bahwa pemberdayaan masyarakat adalah upaya untuk memberikan daya (empowerment) atau penguatan (strengthening) kepada masyarakat. Pemberdayaan masyarakat juga diartikan sebagai kemampuan individu yang bersenyawa dengan masyarakat dalam membangun keberdayaan masyarakat yang bersangkutan sehingga bertujuan untuk menemukan alternatif-alternatif baru dalam pembangunan masyarakat (Mardikantoro, 2014: 202).

Selanjutnya melakukan komunikasi dengan masyarakat yang ada dilingkungan sekitar tambak garam dan difasilitasi oleh kepala desa dan aparatur desa dalam berkomunikasi dan berinteraksi dengan masyarakat. Peneliti juga diberikan kebebasan untuk berinteraksi dan berkomunikasi dengan masyarakat yang dianggap sebagai informan penting dalam pelaksanaan kegiatan penelitian ini.

Pandangan lainya menyatakan bahwa, pemberdayaan masyarakat adalah upaya untuk memampukan dan memandirikan masyarakat yang dilakukan dengan upaya sebagai berikut: Pertama, Enabling yaitu menciptakan suasana atau iklim yang memungkinkan potensi masyarakat 
berkembang. Titik tolaknya adalah pengenalan bahwa setiap manusia, setiap masyarakat memiliki potensi yang dapat dikembangkan. Pemberdayaan adalah upaya untuk membangun daya itu dengan cara mendorong (encourage), memotivasi dan membangkitkan kesadaran (awareness) akan potensi yang dimilikinya serta berupaya untuk mengembangkannya. Kedua, Empowering, yaitu meningkatkan kapasitas dengan memperkuat potensi atau daya yang dimiliki oleh masyarakat. Perkuatan ini meliputi langkah-langkah nyata seperti penyediaan berbagai masukan (input) serta pembukaan akses kepada berbagai peluang yang dapat membuat masyarakat menjadi makin berdayaan. Ketiga, Protecting, yaitu melindungi kepentingan dengan mengembangkan sistem perlindungan bagi masyarakat yang menjadi subjek pengembangan. Dalam proses pemberdayaan harus dicegah yang lemah menjadi bertambah lemah, oleh karena kekurangberdayaan dalam menghadapi yang kuat. Melindungi dalam hal ini dilihat sebagai upaya untuk mencegah terjadinya persaingan yang tidak seimbang serta eksploitasi yang kuat atas yang lemah (Fahrudin, 2012: 96-97).

Inti dari penelitian dan metode PAR ini adalah adanya penyadaran terhadap kemampuan yang dimiliki oleh manusia secara individu dan kelompok. Hal yang dilakukan peneliti dengan datang ke rumah warga untuk mendapatkan informasi tentang situasi dan potensi daerah yang dulu pernah berkembang dan potensi pada masa sekarang yang sedang berkembang. Baik untuk laki-laki dan perempuan pada usia produktif. Data warga bahwa sebagian besar dari penduduk berkerja di tambak garam milik perorangan. Namun, ada juga ibu rumah tangga yang di desa yang bisa membuat telor asin.

Setelah melakukan diskusi dan kajian mendalam masyarakat yang ada, maka diputuskan untuk melakukan penguatan dan pemberdayaan tentang pembuatan telor asin yang biasa dikonsumsi dan dijual oleh masyarakat sekitarnya. Membuat telor asin yang berasal dari telor bebek. Namun, tidak menggunakan bahan yang biasanya seperti tanah yang diberi campuran garam. Tetapi, menggunakan lumpur sisa dari tambak garam sebagai salah satu bahannya. Ini adalah uji coba yang akan dilakukan oleh masyarakat desa pesisir di lembung.

Hal pertama yang dilakukan adalah dengan membeli bahan-bahan dalam proses pembuatan telor asin yang menggunakan lumpur tambak garam seperti telor bebek, ember besar sebanyak empat buah, centong, dan bak. Empat ember ini untuk uji coba lama waktu pembuatan telor asin atau berapa lama telor ini menjadi maksimal keasinannya. Ini semuanya dilakukan oleh warga, dan peneliti hanya sebagai fasilitator. Setelah semua bahan terkumpul dan dibersihkan,

Selanjutnya peneliti dan warga mengambil lumpur tambak garam dengan berkomunikasi atau ijin terhadap penggarap tambak. Antusias terlihat dari ramahnya penggarap tambak dalam memberikan apa yang diinginkan oleh warga bahkan membantu untuk memberikan lumpur yang dianggap baik untuk membuat telor asin. Setelah mengambil lumpur yang di perlukan 
dengan bak besar yang diangkat bersama-sama oleh warga untuk letakkan di balai desa lembung. Kemudian lumpur tersebut dibagi pada semua ember yang sudah disiapkan untuk penampungan lumpur tambak garam.

Pada pembuatan telor asin dengan menggunakan teknik garam yang dicampur tanah atau sekam biasanya dibutuhkan waktu empat atau lima hari. Pada kesempatan ini, diuji coba menggunakan lumpur tambak garam dengan empat ember. Uji untuk ember pertama adalah untuk empat hari, ember kedua untuk lima hari, ember ke tiga untuk enam hari dan ember ke empat untuk tujuh hari.

Setelah menunggu sesusai waktu uji coba tersebut didapati bahwa telor asin yang dipanen pada hari keempat ternyata sudah asin walaupun belum maksimal, sedangkan telor asin yang dipanen pada hari ke-lima, ke-enam dan ketujuh menunjukkan kualitas yang normal seperti telor asin pada umumnya. Secara kualitas dan standart telor asin sudah memadai dan dicoba untuk di konsumsi oleh beberapa tim mahasiswa yang juga bersamaan melakukan pengabdian kepada masyarakat di tempat yang sama. Setelah, waktu uji coba selesai maka penting kiranya dilanjutkan pada produksi yang lebih besar untuk membantu masyarakat sekitar untuk menekan biaya produksi dengan menggunakan lumpur tambak garam yang melimpah dan tidak termanfaat selama ini. Hal ini sebagai upaya Empowering dengan meningkatkan kapasitas dengan memperkuat potensi atau daya yang dimiliki oleh masyarakat. Perkuatan ini meliputi langkahlangkah nyata seperti penyediaan berbagai masukan (input) serta pembukaan akses kepada berbagai peluang yang dapat membuat masyarakat menjadi makin berdayaan.

Terakhir, masyarakat tentu harus terus mendapatkan pembinaan dan pendampingan berkelanjutan dari semua pihak baik dari kalangan akademisi, pemerintahan desa hingga kabupatenm sebagai upaya untuk perlindungan terhadap hak dan peningkatan kapasitan masyarakat daerah pesisir pantai yang ada. Hal ini juga merupakan bagian tahap ketiga dalam teori pemberdayaan.

\section{Kesimpulan}

Pertama, Lumpur dari tambak garam yang berasal dari endapan garam berupa lumpur yang biasanya di buang oleh para petani tambak bisa dimanfaatkan sebagai bahan untuk pengasin telur bebek yang biasanya terbuat dari campuran tanah yang diberi garam. Kedua, Hasil uji coba yang dilakukan oleh masyarakat yang juga di fasilitasi oleh peneliti tentang pemanfaatan lumpur tambak garam untuk menjadi salah satun bahan yang bermanfaat bagi masyarakat pesisir untuk membuat telor asin, dalam meningkatkan kualitas ekonomi pembuatan telor asin berhasil dengan baik. Ketiga, Hasil telor asin dengan memanfaatkan lumpur tambak garam cukup baik dan layak untuk di konsumsi selain itu bahan lumpur tambak garam yang melimpah di daerah pesisir madura menjadi bahan alternatif dalam membuat telor asin. 


\section{Daftar Pustaka}

Abadi, M. M. (2019). Peneliti Senior Madura [Wawancara Langsung].

Ardiyanti, S. T. (2016). "Produksi Garam dalam Negeri" dalam Info Komoditi Garam. Jakarta: Badan Pengkajian dan Pengemban Perdagangan KPRI dan Al-Mawardi Prima.

Corey, S. M. (1953). Action Research to Improve School Practices. New York: Bureau of Publications, Teachers College, Columbia University.

Fahrudin, A. (2012). Pemberdayaan, Partisipasi dan Penguatan Kapasitas, Masyarakat. Bandung: Humaniora.

LPM IAIN Madura. (2018). Materi Pemberdayaan Masyarakat dengan Pendekatan ABCD dan PAR. Pamekasan: LPM IAIN Madura.

LPM IAIN Sunan Ampel Surabaya. (2008). Modul Pelatihan Kuliah Kerja Nyata (KKN) Transformatif IAIN Sunan Ampel Surabaya. Surabaya: LPM IAIN Sunan Ampel Surabaya.

Mardikantoro, T. (2014). CSR: Corporate Social Responsibility (Tanggungjawab Sosial Korporasi). Bandung: Alfabeta.

Munadi, E. (2016). Dilema Pergaraman di Indonesia. In Info Komoditi Garam. Jakarta: Badan Pengkajian dan Pengemban Perdagangan KPRI dan Al-Mawardi Prima.

Republik Indonesia. Undang-Undang Republik Indonesia Nomor 14 Tahun 2005 tentang Guru dan Dosen, (2005).

Siap Bangun Negara. (2019). Pulau Madura Pulau Garam Indonesia Indonesia Baik. Retrieved 11 January 2021, from http://indonesiabaik.id/infografis/pulau-madura-pulau-garam-indonesia

Winter, R. (1989). Action-Research and the Nature of Social Inquiry: Professional Innovation and Educational Work. Aldershot: Gower Publishing Company. 